気管，気管支内悪性腫瘍に対し気管支鏡下半導体レーザー治療を含む 集学的治療を行った 3 例

山田 徹 1 - 小林良樹 2 . 北 英夫 2 .

安場広高 $2 \cdot$ 千葉 渉 1 . 人見滋樹 1

要旨一一背景 . 高出力半導体 (GaAlAs) レーザー装置の開発により気管, 気管支内の悪性腫瘍に対して気管支鏡下の 半導体レーザー治療が可能となった．以前より使用されていたNd-YAG などの高出カレーザーよりも装置が小型, 軽量 という利点があり, 同等の臨床効果がある . 症例 . 外科的切除術の適応とならない気管癌 1 例, 腎細胞癌, 乳癌の気管 支内転移各 1 例に対して，気管支鏡下に高出力半導体 (GaAlAs) レーザー装置 (UDL-60，オリンパス社製) を用いて 半導体レーザー治療を行い，全身化学療法と体外放射線照射を併用した .レーザー治療の総エネルギー量は光れ午れ

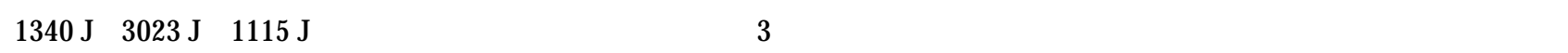
喘鳴, 咳嗽の呼吸器症状の消失を認めた .また, 全身化学療法と体外放射線照射を併用することで 2 年以上の比較的長 期にわたり，気道内局所再発による呼吸器症状の再発を防ぐことが出来た . 結論 . 高出力半導体レーザー治療は気管， 気管支の悪性腫痬に対して局所制御による呼吸症状の消失をもたらすのみではなく，全身化学療法，体外放射線照射と の併用により長期にわたり呼吸器症状の再発を防ぎうる . (肺癌 . 2005;45:139-143)

索引用語——気管癌, 気管支内腫瘍, 気管支鏡, 半導体レーザー

\title{
Three Cases of Tracheal and Endobronchial Malignancies Treated by High-Power Diode (GaAIAs) Laser Combined With Chemoradiotherapy
}

Tetsu Yamada'; Yoshi ki Kobayashi2; Hi deo Ki ta²;

Hi rotaka Yasuba2; Wataru Chi ba1; Shi geki Hi tomi ${ }^{1}$

AB STRACT — Background. Development of a high power diode (GaAlAs) laser system has enabled the treatment of tracheal and endobronchial malignancies via bronchoscopy. Compared with the previously used Nd-YAG laser, GaAlAs laser system is more compact and more portable and has an equal clinical effect. Cases. We encountered 3 cases of inoperable tracheal cancer and endobronchial metastasis of renal cell cancer and breast cancer. All the patients complained of respiratory symptoms including bloody sputum, wheezing and cough. They were treated by the GaAlAs laser system (UDL-60, Olympus) via bronchoscopy, combined with systemic chemotherapy and external irradiation. The total amount of energy delivered by diode laser treatments were $1340 \mathrm{~J}, 3023 \mathrm{~J}$ and $1115 \mathrm{~J}$. No complication was encountered. In all the cases, respiratory symptoms disappeared immediately after diode laser treatment, and local control for more than 2 years was obtained by the combination with systemic chemotherapy and external irradiation. Conclusion. Laser treatment by the GaAIAs laser system should be considered as a therapeutic option for long term control of respiratory symptoms in patients with tracheal and endobronchial malignancies. (J J LC. 2005;45:139-143)

KEY WORDS — Tracheal cancer, Endobronchial tumor, Bronchoscopy, Diode laser

高槻赤十字病院 1 呼吸器外科, 2呼吸器・アレルギー科

別刷請求先：山田徹，高槻赤十字病院呼吸器外科, ₹ 569-1096

大阪府高槻市阿武野 1-1-1(e-mail: tetsuymd@takatsuki.jrc.or.jp) .

Division of ${ }^{1}$ Thoracic Surgery, ${ }^{2}$ Respiratory and Allergy Medicine, Takatsuki Red Cross Hospital, J apan.
Reprints: Tetsu Yamada, Division of Thoracic Surgery, Takatsuki Red Cross Hospital, 1-1-1 Abuno, Takatsuki-shi, Osaka 569-1096, Japan (e-mail: tetsuymd@takatsuki.jrc.or.jp).

Received October 21, 2004; accepted March 2, 2005.

(C) 2005 The J apan Lung Cancer Society 


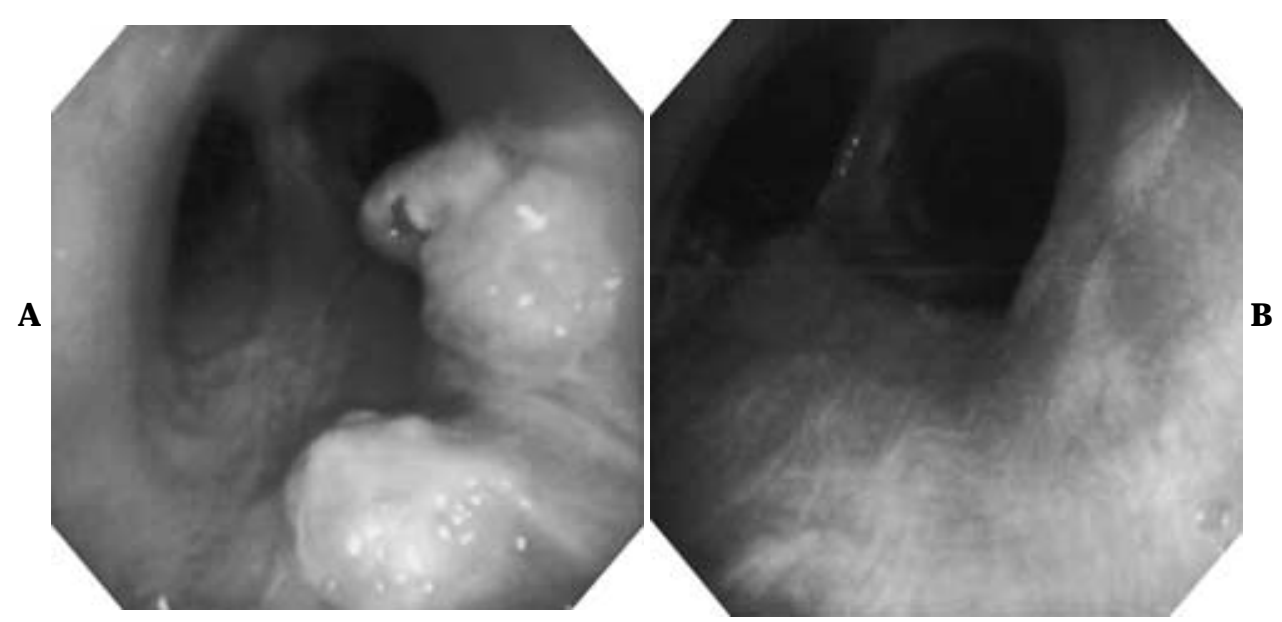

Figure 1. Bronchoscopic findings of case 1, before laser treatment (A) and after laser treatment (B).

気管，気管支内悪性腫瘍に対し気管支鏡下半導体レー ザー治療を行い，全身化学療法と体外放射線照射を併用 した 3 例を報告する．

症例 1 (69 歳男性)

1995 年 9 月に当院で右肺上葉の扁平上皮癌に対して 右肺上葉切除と ND2a リンパ節郭清を行った . 病期は PTINOMO , stage IA であった . 術前の気管支鏡検査では 気管には特に異常所見を認めなかった．弚の後外来で経 過観察していたが, 1998 年 11 月に黑色の血痰を自覚し， CT にて気管内に腫瘤影を認めた.11 月 27 日に気管支鏡 検査を行ったところ，気管中部から気管分岐部より口側 約 $2 \mathrm{~cm}$ まで,3 時から 7 時にかけて白苔を伴うポリープ 状の腫瘤を認めた (Figure 1A) . 腫瘍生検による病理診断 は扁平上皮癌であった . 12 月 24 日にレーザーフィルタ 付き気管支鏡 IT-200 と高出力半導体 (GaAIAs) レーザー 装置 (UDL-60，オリンパス社製）を用いて 20〜40 W，1 回 1.5 秒の出力設定で照射を繰り返し合計 $1340 \mathrm{~J}$ の半導 体レーザー治療を行った . 1 月 5 日の気管支鏡では腫瘍 は半分に縮小していたが，扁平上皮癌が残存していた． 1999 年 1 月 6 日にシスプラチン (CDDP) $110 \mathrm{mg}+$ ドセ タキセル (DTL) $80 \mathrm{mg}$ を投与した . 1 月 20 日から 3 月 3 日の間に 1 日 $2 \mathrm{~Gy}$ を 30 回（前後対向 $40 \mathrm{~Gy}$ と斜入対向 $20 \mathrm{~Gy}$ )計 $60 \mathrm{~Gy}$ の体外放射線照射を行った . 3 月 15 日に CDDP $110 \mathrm{mg}+\mathrm{DTL} 80 \mathrm{mg}$ を投与した .4 月 30 日の気管 支鏡検査では瘕痕はさらに収縮し狭窄は認めなかった (Figure 1B).6月 4 日にCDDP $100 \mathrm{mg}+$ ビノレルビン $(\mathrm{VNR}) 30 \mathrm{mg}+$ +マトマイシン (MMC) $10 \mathrm{mg}, 6$ 月 11 日 VNR $30 \mathrm{mg}$ を投与した。. 1999 年 12 月に両側肺炎を発 症し人工呼吸を開始したが, 多藏器不全が進行し人工呼
吸器からの離脱は出来なかった、気管支鏡下レーザー治 療を行った後 2 年 8 ケ月経過した 2001 年 7 月 31 日に死 亡した . 剖検を行ったが , レーザー照射部位及び光の他 の部位にも扁平上皮癌の再発は認めなかった．1995 年 9 月に手術を行った右肺上葉の扁平上皮癌は 2001 年 7 月 31 日の死亡時の剖検で気管支断端，リンパ節，关の他の 部位にも再発転移を認めず，気管に発症した扁平上皮癌 は異時性多発癌と考えられる .

\section{症例 2 (78 歳女性)}

腎細胞癌にて 1998 年 2 月 9 日に他院で左腎藏摘出術 を行った. 2001 年 2 月頃から咳嗽が出現した . 胸部レン トゲン ,CT で左肺門部に腫瘤影を認めた 4 月 20 日に施 行した気管支鏡ブラシ細胞診で腺癌を認め腎細胞癌の転 移と診断し,5月 7 日より週 2 回, 1 回 100 万単位のイン ターフェロン $\alpha$ による治療を 15 回行った . 2002 年 2 月頃から喘鳴が出現した、気管支鏡検査で左上葉気管支 内の腫瘍を認め ( F i gure $2 \mathrm{~A})$ ，生検で腎細胞癌の肺転移と 診断した. 2002 年 2 月 5 日より同部に対して気管支鏡下 に3 回に分けて計 3023J (1029 J，1539J，455J)の半導 体レーザー治療を行った.初回治療より 36 日目の気管支 鏡検査では肉眼的に腫瘍の消失が確認された (Figure 2 B ) . 同部に対して 1 日 $2 \mathrm{~Gy}, 30$ 回で計 $60 \mathrm{~Gy}$ の体外放 射線照射を行った，弚の後脳転移，骨転移に対して治療 を行ったが 2004 年 10 月の現在, 喘鳴などの呼吸器症状 の訴えはなく，身体所見，レントゲン，CTでも左上葉気 管支の狭窄の再発は認めていない .

\section{症例 3 (50 歳女性)}

2000 年 12 月に乳癌にて当院で右乳房切断術を行っ 


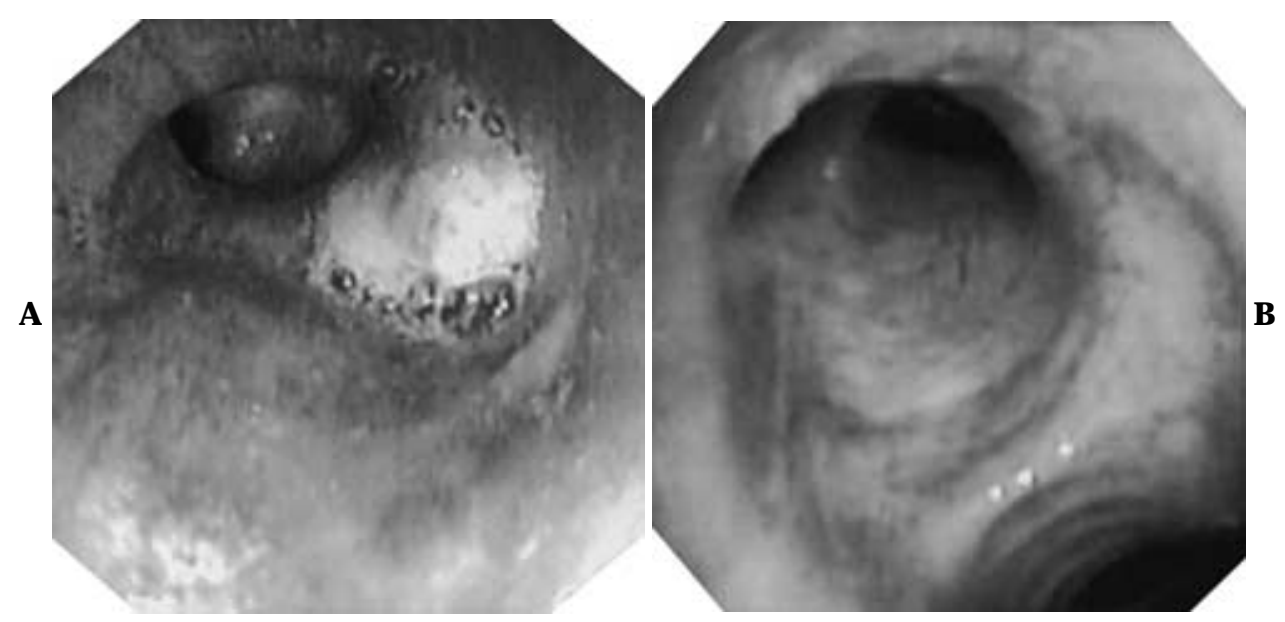

Figure 2. Bronchoscopic findings of case 2, before laser treatment (A) and after laser treatment (B).

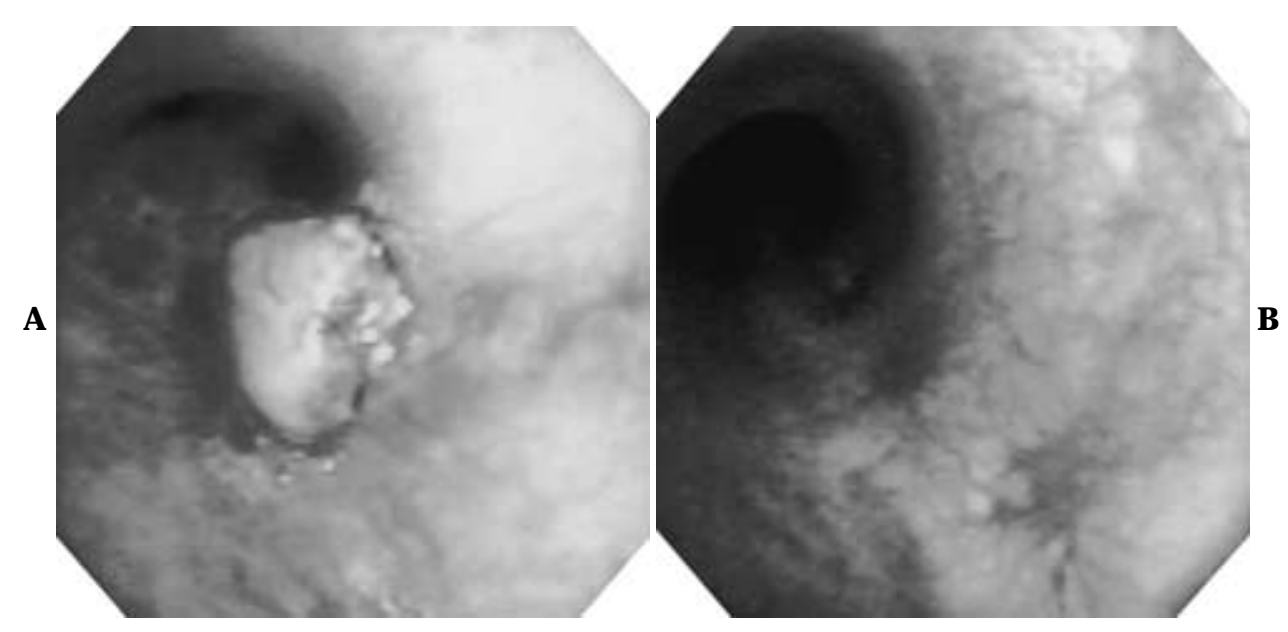

Figure 3. Bronchoscopic findings of case 3, before laser treatment (A) and after laser treatment (B).

た. 2001 年 9 月 10 日には肺腺扁平上皮癌にて左肺上葉 切除とND2a リンパ節郭清を行った . 肺癌の病期は pT1N0M0,stage IA であった.外来にて経過観察中, 右肺 下葉に乳癌の肺転移が出現し, 2002 年 1 月 7 日に右肺 $\mathrm{S}^{10}$ 部分切除術を行った.2 月 19 日よりDTL $34 \mathrm{mg}$ の少 量分割投与を開始したが咳嗽が増悪した.3 月 19 日の気 管支鏡検査で左主気管支内に腫瘍を認め(Figure 3A), 生 検の結果腫瘍は乳癌の肺転移と診断した.3 月 22 日に気 管支鏡下に $1115 \mathrm{~J}$ の半導体レーザー治療を行った . 15 日後の気管支鏡検査では治療部位に㓔痕のみを認めた (Figure 3B ). 同部に対して 1 日 $2 \mathrm{~Gy}, 30$ 回で計 $60 \mathrm{~Gy}$ の体外放射線照射を行った.DTLの少量分割投与は計 $340 \mathrm{mg}$ を投与した . 2004 年 10 月の現在, 呼吸器症状の 訴えはなく, 身体所見, レントゲン, CT でも左主気管支
の狭窄の再発は認めていない .

3 例とも気管支鏡下の半導体レーザー治療に伴う合併 症はなく, 治療後早期より呼吸器症状の消失を認めた . 2 年以上の比較的長期にわたり呼吸器症状の再発, 腫瘍 の局所再発は認めておらず良好な結果が得られた . 3 例 の治療概略を表に示した (Table 1).

\section{考 察}

気管原発の肺癌は森田らの本邦剖検例を検討した報告 によると, 肺癌 400 例に対して 1 例と稀で, 弚のうち扁 平上皮癌は $61 \%$ であった .1他の報告では腺樣囊胞癌の しめる割合が高いが , これは腺樣囊胞癌の方が臨床経過 が長く手術の適応となるものが多いためと考えられる . 気管癌は気管切除形成術とリンパ節郭清術による外科手 
Table 1. Background, Treatment and Result of 3 Cases

\begin{tabular}{|c|c|c|c|}
\hline & Case 1 & Case 2 & Case 3 \\
\hline Age/sex & $69 / M$ & $78 / F$ & $50 / \mathrm{F}$ \\
\hline Primary lesion & Tracheal Sq. cell ca. & Lt. renal cell ca. & Rt. breast cancer \\
\hline Complaint & Bloody sputum & Wheeze & Cough \\
\hline Location & Trachea & Lt. upper br. & Lt. main br. \\
\hline $\begin{array}{l}\text { Laser irradiation } \\
\text { (total energy/times) }\end{array}$ & $1340 \mathrm{~J} / 1$ & $3023 \mathrm{~J} / 3$ & 1115 J/1 \\
\hline Chemotherapy & $\mathrm{CDDP}^{*}+\mathrm{DTL} \dagger$ & INF $\alpha \ddagger$ & DTL \\
\hline Radiation & $60 \mathrm{~Gy}$ & $60 \mathrm{~Gy}$ & $60 \mathrm{~Gy}$ \\
\hline Follow-up & 32 mos. & 32 mos. & 31 mos. \\
\hline Result & $\begin{array}{l}\text { No recurrence } \\
\text { (autopsy) }\end{array}$ & $\begin{array}{l}\text { No relapse of } \\
\text { airway stenosis }\end{array}$ & $\begin{array}{l}\text { No relapse of } \\
\text { airway stenosis }\end{array}$ \\
\hline
\end{tabular}

${ }^{*}$ Cisplatin, $\dagger$ Docetaxel, $\ddagger$ Interferon $\alpha$.

術の適応となりうるが, 症例 1 は以前に肺癌に対して右 肺上葉切除の既往があり，呼吸機能の問題から気管支鏡 下レーザー照射と全身化学療法, 放射線照射による治療 を選択した。

転移性肺腫瘍により気管支狭窄をきたす機転として は，気管支内腔への転移による管内性のものと，気管， 気管支周囲，リンパ節への転移，腫大による管外性のも のとが考えられる．管外性の狭窄に対しては気管支壁穿 孔，出血などの合併症を避けるため気管支鏡下ステント 留置などが選択される．レーザー治療が有効となるのは 管内性の転移性肺腫瘍である. 転移性肺腫瘍のうち気管 支壁, 気管支粘膜への転移による厳密な意味での気管支 内転移は稀であるが，，気管支周囲への転移巣より気管 支内腔へと進展する腫瘍も治療方針の上では，この管内 型の転移性肺腫瘍に含まれる .

呼吸器領域での内視鏡下レーザー治療としては従来， 高出力レーザーと呼ばれている Nd-YAG レーザー, アル ゴンレーザーなどが使用されてきた . 半導体レーザーは 以前, 低出カレーザーと呼ばれ疼痛緩和や皮膚科, 眼科 領域での使用に限られてきたが, 近年半導体レーザー素 子の開発により高出力半導体レーザーの臨床での使用が 可能となった . 我々が使用したオリンパス社製のULD60 は最高で $60 \mathrm{~W}$ の高出力であり，全症例で非接触型の プローブを用いて約 20 分から 30 分以内での処置が可能 であった .レーザー装置本体は軽量かつ小型で, 家庭用 $100 \mathrm{~V}$ 電源での使用が可能である. Ga，Al，As を組み合 わせた半導体素子により $805 \mathrm{~nm}$ の波長のレーザーを発 生し, 波長 $1064 \mathrm{~nm}$ の Nd-YAG レーザーと, 生体への吸 収特性及び臨床効果はほぼ同等である 3.5

気管支鏡下レーザー治療は気道内腫瘍による気道狭窄 に対して気道開存目的での使用例が多いが, 気道出血に 対して止血を目的として使用される場合もある 6 気管， 気管支内の良性腫瘍に対しては第一選択となりうる？
一方で, 気管支鏡下レーザー治療の欠点としては，処置 中の発煙による呼吸困難が第一に挙げられる.我々も実 際に，気管支過誤腫に対して気管支鏡下レーザー治療を 試みたが, 患者の不快感が強く充分な効果が得られず断 念した症例を経験した．気管支鏡下の処置に耐えうる全 身状態であること，場合によっては全身麻酔下での処置 が必要となる.光の他の合併症としては，気管支壁穿孔， 出血, 窒息のほか気道内発火の報告もある. 藤澤らは中 枢気道狭窄に対してレーザー治療を行った 170 例中 7 例， $4.1 \%$ に合併症が見られたと報告している８対策と して, 気道内発火について石原らは気管チューブ, 気管 支鏡，レーザー照射プローブと照射部位の間に充分な距 離をとること，繰り返し照射を行う際には炭化物を除去 してから行うことが重要であると述べている 9 楠らは Nd-YAGレーザーを気管支鏡下に使用した症例を検討 し , 非接触型のプローブと比べて接触型のプローブの方 が発煙, 壊死物質が少なく合併症が少なかったと述べて いる 10

我々は体外放射線照射と全身化学療法を併用すること で 2 年以上と比較的長期の局所制御を得ることが出来 た . 半導体レーザーを気管, 気管支内悪性腫瘍に対して 用いることによる予後の改善はレーザー治療による局所 制御だけではなく，気道閉塞症状の改善により体外放射 線照射, 全身化学療法, あるいは手術などの治療を行い やすくするといった効果にもよると考えられる．

\section{まとめ}

肺癌根治術後の気管癌，転移性肺腫痬といずれも外科 的切除による根治は困難な症例に対して気管支鏡下に半 導体レーザー治療を行った . 半導体レーザー治療に伴う

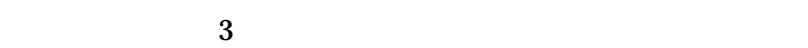
鳴, 咳嗽の呼吸器症状の改善を認めた .また, 全身化学 療法と体外放射線照射を併用することで 2 年以上の比較 
的長期の間, 気道内局所再発による呼吸器症状の再発を 防ぐことが出来た .

\section{REFERENCES}

1. 森田豊彦 肺癌症例と比較した気管癌および気管分岐部 癌の頻度と特徵 (前編: 頻度·他) 日本病理剖検輯報 (1958～1985 年)による検討. 呼吸. 1989;8:1104-1112.

2. Braman SS, Whitcomb ME. Endobronchial metastasis. Arch Intern Med. 1975;135:543-547.

3. Wyman A, Duffy S, Sweetland HM, et al. Preliminary evaluation of a new high power diode laser. Lasers Surg Med. 1992;12:506-509.

4 . 鈴木博昭, 増田勝紀, 福富久之, 他. 高出力半導体レー ザー手術装置 Diomed 25 の臨床的評価 . 日本レーザー医 学会誌. 1994;15:1-6.

5 . 石黑 崇, 澤 祥幸, 吉田 勉, 他. 当院における接触
型半導体レーザーを用いた気管・気管支悪性腫瘍の症例 検討 . 癌と化学療法 . 2002;29:2205-2208.

6 . 常塚宣男, 本多 桂, 竹内一雄, 他. 難治性気道出血に対 する高出力半導体 (GaAlAs) レーザーの使用経験 . 気管 支学. 1997;19:167-171.

7. 石川紀彦,橋爪敏彦, 石川智啓, 他.肺癌に合併した気管 支炎症性ポリープの 1 治験例 . 高出力半導体レーザーの 使用経験 . 胸部外科 . 54:437-440.

8. 藤澤武彦, 斎藤幸雄, 飯笹俊彦, 他.レーザーによる気道 狭窄の治療. 呼吸 . 2003;22:146-149.

9 . 石原弘規, 高平陽子 , 村岡正敏 , 他 .内視鏡下レーザー照 射時の高吸入酸素濃度は気道内発火の主たる原因となる か? 全静脈麻酔中の気道内発火事故の 1 症例 . 麻酔. 2002;51:1359-1362.

10 . 楠洋子, 梁 尚志, 玉野井優水, 他.気道狭窄に対する Nd-YAG レーザーの適応と限界. 気管支学 . 1993;15:738744. 